\title{
Participatory Forest Management for the Sustainable Management of the Sundarbans Mangrove Forest
}

\author{
Anjan Kumer Dev Roy and Khorshed Alam \\ School of Accounting, Economics and Finance, Faculty of Business and Law, \\ University of Southern Queensland, Australia, Toowoomba, QLD 4350, Australia
}

Received 2010-09-24, Revised 2012-08-21; Accepted 2012-09-05

\begin{abstract}
People's participation in forest management has become successful in many countries of the world. The Sundarbans is the single largest mangrove forest in the world, bearing numerous values and holding importance from economic, social and ecological perspectives. It is the direct and indirect sources of the livelihood of 3.5 million people. As a reserve forest, government is always providing extra care through state monopolies for its management with the introduction of policies and guidelines. Bangladesh, being the signatory of a number of international conventions and treaties, is committed to preserve its resources. In spite of all these initiatives, its resources including biodiversity have been losing gradually over the last few decades. Thus, sole management by the Forest Department has raised the question of its sustainability. The need for a critical analysis of the options of present management structure and the involvement of local people and their power-sharing to reduce degradation is inevitable. In this study, we examine the prevailing management crisis of the state machinery of forest bureaucracy and forwarded the argument for community involvement through community-based forest management for sustainable use of its resources.
\end{abstract}

Keywords: Participatory Management, Policy Option, Sundarbans Mangrove Forest, Sustainability

\section{INTRODUCTION}

The single largest tract of natural mangrove forest of the world is the Sundarbans of Bangladesh consisting a total area of 601,700 hectare which represents $4.07 \%$ of the land mass of the country and $40 \%$ of total forest land (MOEF, 2009). This mangrove forest contains 334 species of trees, shrubs and epyphites and 269 species of wild animal and is different from other mangrove forest in that it is dominated by Rhizophoraceae tree vegetation. Its existence and exceptional mangrove ecology and ecosystem support a large group of fish, shrimp, edible crab and also supply food and livelihood to 3.5 million dependent coastal communities other than precious wood and Non-Wood Forest Products (NWFPs). The government of Bangladesh declared it as World Heritage Site in 1999 followed by UNESCO's declaration. Anthropogenic pressure from depending communities is causing gradual resource reduction (Roy et al., 2012; Roy, 2009a) In spite of continued degradation, this forest contributes $3 \%$ to the country's gross domestic product (Khan et al., 2008) against 5\% contribution of the whole forestry sector (MOEF, 2005).

Top-dying disease and overharvesting have caused $50 \%$ reduction of tree density and posed a threat to its sustainability (Kabir and Hossain, 2008). As a reserve forest, Forest Department (FD) controls overall top down management of the Sundarbans with no involvement of the local people and perceives resource management from their own perspectives. For instance, it focuses on timber production overlooking the contributions of NWFPs to the local livelihood and forest sustainability. FD treats the forest as a source of revenue where resources are over-exploited and not ideal for its sustainable management (Tamang, 1994). Despite its declaration as the World Heritage site, no comprehensive management system for wood and NWFPs has yet been undertaken to stop the degradation. Present management

Corresponding Author: Anjan Kumer Dev Roy, School of Accounting, Economics and Finance, Faculty of Business and Law, University of Southern Queensland, Australia, Toowoomba, QLD 4350, Australia 
system has failed to realise true sustainable indicators from overall stakeholders' viewpoints, for instance, avoidance of local people's customary rights and knowledge in resource conservation. Thus, this needs reformulation of present management policy by examining the introduction of Participatory Forest Management (PFM) which has become successful in different countries as a new paradigm for sustainable forest management (Stone et al., 2008). Institutional framework under PFM may not only be successful in promoting effective forest management, but also conducive to an equitable distribution of benefits obtained from managing the forests. Tewari (2006) found this structure as a tried and tested one throughout the world for specially collection and marketing of NWFPs by the local people. The main feature of PFM is the recognition and combination of social, economic and ecological values. It has emerged as a promising approach to address the issues for sustainable forest management (Misra and Kant, 2005). Although PFM in the form of social forestry has been successful in Bangladesh, there is no research on its implication in case of the Sundarbans. From this consequence, policy-makers, researchers, planners and development practitioners have been in deep concern for the sustainable management of the Sundarbans. This study is aiming at evaluating present management strategies in extracting resources and substantiates the argument for adoption of PFM as an option with the involvement of local people. In this regard, it also presents some of the examples of PFM programmes of Bangladesh with the distribution of financial benefits to the participants and rationality of the replication of such interventions for its sustainability.

\subsection{History of the Sundarbans' Regulations and Policies}

The Sundarbans has been under some sort of management since 1875, although no specific information is available about its conservation practices during that period. Before declaring as a reserve forest in 1978, a number of comprehensive forestry management plans were adopted. Several studies also underscored the need for wildlife conservation due to the emphasis on revenue collection by enforcing simple felling rules. The Sundarbans has always been managed as a contiguous block of mangrove forest with no permanent human habitation inside. Afterwards, policy aims to assure the sustainable harvesting of forest products and maintains this coastal zone in a way that meets the needs of the local human population although degradation continues.

In fact, first formal forest policy in 1894 was declared to administer the forest for the overall benefit of the people and interest of the local community got high priority. The main aim of the policy was to extract resources which caused degradation of the forest. To address the degradation, 'Lloyd Plan' and 'Working Plan' were introduced during the period 1904-08 as a basis of its founding administration for this forest but failed to reverse or reduce the degradation. During the Pakistan era (1947-71), forest policy was undertaken for huge extraction of resources where rights of forest people were denied (Kabir and Hossain, 2008). After the independence in 1971, Bangladesh adopted the first National Forest Policy in 1979, but again failed to address issues such as sustainability, community participation and their livelihood. The violation of inclusion approach is still going on although revised Forest Policy 1994 leaves provisions for preservation and management of designated forest through a participatory approach with local residents (Muhammed et al., 2005). Consequently, due to a lack of defined ownership and established rights, huge dependent population surrounding the Sundarbans have not yet been able to be a part of the strategies and activities aimed at conserving the forest and using its resources sustainably. The historical policy changes are presented in Table $\mathbf{1}$.

\subsection{An Evaluation of the Community Forestry in Bangladesh}

Participatory forestry is practical in Bangladesh in a limited scale. In the latest National Forest Policy of 1994, the Government incorporated the policy of social forestry and agro-forestry concept to include the poor and interested community in the regeneration on the basis of a benefit-sharing arrangement (no-cost sharing). The policy also declares an increase of $20 \%$ of the forest including a $10 \%$ increase of the reserve forest by 2015 (GOB, 1994). Against this target by 2002 forest resource cover was increased by only $1 \%$ (Muhammed et al., 2005). The community forestry in Bangladesh was started in 1979 at Betagi and Pomora mouzas in Chittagong district. The project was launched covering 160 hac of Khas (uncultivated) land owned by the Government with 83 participants initially and subsequently extended to over another 205 hac of Khas land with another batch of 243 landless people. Each participant was given 1.62 hac of land to grow tree and horticulture with necessary financial and technical assistance by the FD. Islam et al. (2005) found that the project generated significant benefits; an input-output ratio of about 2 at Betagi and 2 at Pomora. The internal rate of return was found to be surprisingly very high$104 \%$ at Betagi and $90 \%$ at Pamora. Annual income of the villagers also doubled in 1994 with compared to 1985 with the change of their socio-economic status. 
Another typical example is the application of participatory strategy in three divisions of Sal forests in Dhaka, Tangail and Mymensingh districts of the country. The participatory forestry in that forest was very challenging for the FD to justify the end of overuse and degradation of forest through the involvement of local people. Benefit Cost Ratios of the project are shown in Table 2. The plantation of agro forestry was found most profitable compared to woodlot although participants realised all the three products were profitable because of no direct cost involvement (Muhammed et al., 2008). Roy (2009b) claimed the patronisation of the FD towards the resettlers in this project by declining indigenous participation. It was also identified that no in-depth stakeholder analysis was done; rather, the programme was donor-driven and thus adopted a top-down policy approach.

Table 1. History of policy changes in the management of the Sundarbans

\begin{tabular}{|c|c|c|c|}
\hline Periods & Policy initiatives & Key objectives & Main achievements and outcomes \\
\hline $\begin{array}{l}\text { Pre-British Rule } \\
\text { (before 1757) }\end{array}$ & $\begin{array}{l}\text { No management } \\
\text { policies }\end{array}$ & Resource extraction & Abundance of resources \\
\hline \multirow[t]{3}{*}{$\begin{array}{l}\text { British Rule } \\
(1757-1947)\end{array}$} & $\begin{array}{l}\text { Charts of India Forest, } \\
1855\end{array}$ & $\begin{array}{l}\text { Conservation idea } \\
\text { generation }\end{array}$ & $\begin{array}{l}\text { Awareness with importance } \\
\text { realisation and first regulations } \\
\text { regarding felling trees for revenues }\end{array}$ \\
\hline & $\begin{array}{l}\text { Declaration of }{ }^{`} \text { Reserve } \\
\text { Forest', 1875-76 under } \\
\text { Forest Act } \\
\text { Forest }\end{array}$ & Controlling the resources & Revenue generation \\
\hline & Act of India, 1894 & $\begin{array}{l}\text { Introduction of formal } \\
\text { forest policy to be administered } \\
\text { targeting benefits with } \\
\text { commercial management of } \\
\text { wood and NWFPs for public } \\
\text { at large and for the local people } \\
\text { under regulations and rights. }\end{array}$ & Resource extraction \\
\hline \multirow[t]{2}{*}{$\begin{array}{l}\text { Pakistan Rule } \\
(1947-1971)\end{array}$} & $\begin{array}{l}\text { Forest policy of } \\
\text { Pakistan, } 1955\end{array}$ & $\begin{array}{l}\text { Classification of the Sundarbans } \\
\text { on the basis of its utility and } \\
\text { objectives }\end{array}$ & $\begin{array}{l}\text { Over exploitation of forest resources } \\
\text { from (East Pakistan now Bangladesh) } \\
\text { the Sundarbans (Hakim, 2007) }\end{array}$ \\
\hline & $\begin{array}{l}\text { Revised Forest policy } \\
\text { of Pakistan, } 1962\end{array}$ & $\begin{array}{l}\text { Acceleration of timber } \\
\text { harvesting. Speed up regeneration } \\
\text { for increased harvesting. } \\
\text { Ignorance of the principle of } \\
\text { sustainable forest use and rights } \\
\text { of local people }\end{array}$ & $\begin{array}{l}\text { Protection of wildlife and habitats. } \\
\text { Realisation of overuse. Ecological } \\
\text { degradation }\end{array}$ \\
\hline \multirow[t]{3}{*}{$\begin{array}{l}\text { Post-colonial } \\
\text { (1971-present) }\end{array}$} & $\begin{array}{l}\text { National Forest } \\
\text { Policy, } 1979\end{array}$ & $\begin{array}{l}\text { Qualitative improvement based } \\
\text { on modern trend and technology } \\
\text { for extraction and utilisation of } \\
\text { forest resources. }\end{array}$ & $\begin{array}{l}\text { There were inconsistencies as } \\
\text { conservation leaves little incentive } \\
\text { to expand forest-based industries } \\
\text { and became detrimental to forest } \\
\text { health by increasing degradation } \\
\text { through illegal harvesting } \\
\text { (Muhammed } \text { et al., 2008). }\end{array}$ \\
\hline & & Coastal mangrove plantation. & $\begin{array}{l}\text { Inappropriate land tenure agreement } \\
\text { caused illegal cut of mangrove trees } \\
\text { and encroachment of the land } \\
\text { (Muhammed et al., 2008). }\end{array}$ \\
\hline & $\begin{array}{l}\text { Revised National } \\
\text { Forest policy, } 1994 \\
\text { (Although the Sundarbans } \\
\text { is the largest Mangrove } \\
\text { forest of the world, there } \\
\text { were not any separate } \\
\text { agenda or policy directives } \\
\text { for its management. Here } \\
\text { the main management } \\
\text { aspects are depicted from } \\
\text { the whole policy.) }\end{array}$ & $\begin{array}{l}\text { Multi-dimensional uses of its } \\
\text { resources including water and } \\
\text { fish. Leaving the bio-environment } \\
\text { intact and consideration of global } \\
\text { warming and climate change for } \\
\text { its existence. } \\
\text { Use of appropriate extraction } \\
\text { technology. Identification of } \\
\text { protected areas. Ensuring } \\
\text { participation of local people. }\end{array}$ & Sustainable management \\
\hline
\end{tabular}


Table 2. Summary of benefits of some implemented community managed forestry projects

\begin{tabular}{|c|c|c|c|c|}
\hline Name of the project & Period & Beneficiary & IRR \& ERR & $\mathrm{B} / \mathrm{C}$ ratio \\
\hline $\begin{array}{l}\text { The Betagi-Pomora } \\
\text { Community project }\end{array}$ & 1985-1994 & Local people and FD & $\begin{array}{l}\text { IRR- 104\% (for Betagi) } \\
\text { and 90\% (for Pamora) } \\
\text { (Islam et al., 2005) }\end{array}$ & 2 (Islam et al., 2005) \\
\hline $\begin{array}{l}\text { The North-Bengal } \\
\text { Community Forestry } \\
\text { Project }\end{array}$ & 1985-1994 & Local people and FD & $\begin{array}{l}\text { IRR- } 42 \% \text { (whole } \\
\text { agroforestry). } 250 \% \text { (for } \\
\text { community) (Islam et al., 2005) }\end{array}$ & 1.95 (Islam et al., 2005) \\
\hline $\begin{array}{l}\text { ADB-assisted program } \\
\text { throughout the sal } \\
\text { forest }\end{array}$ & 1988-1994 & Local people and FD & $\begin{array}{l}\text { IRR- } 0.38 \% \text { (Safa et al., } \\
2004)\end{array}$ & $\begin{array}{l}\text { [1.64 (agro-forestry), } \\
1.47 \text { (strip plantation } \\
\text { and } 0.86 \text { (woodlot)] } \\
4.13 \text { (Safa } \text { et al., } 2004)\end{array}$ \\
\hline $\begin{array}{l}\text { Farming system research } \\
\text { and development } \\
\text { programme, Bandarban }\end{array}$ & 1996- & Local people and FD & $\begin{array}{l}\text { ERR- } 70 \% \text { (for Group-1) } \\
\text { ERR-112\% (for } \\
\text { Group -2) (Islam et al., 2005) }\end{array}$ & $\begin{array}{l}1.2 \text { (average of } 4 \text { Research } \\
\text { components) and } 2.3 \\
\text { (average of } 7 \text { development } \\
\text { components) (Islam et al., 2005) }\end{array}$ \\
\hline
\end{tabular}

The necessity of local participation in the participatory management was not specifically recognised by the policy-makers.

For successful partnerships, sharing of views, resource management and benefits between the groups is inevitable. From the participatory management experience in Bangladesh, it is found that FD is the main stakeholder who takes decisions unilaterally. Participants had no role in planning and management of forest resources. The most destructive one was to allow outsiders as participants ignoring the local people. This denotes the chauvinism of FD over the management where local level institutions were not developed and no operational plan for community involvement was introduced. This experience however, needs future participatory management intervention to investigate the potential for combining existing methods of stakeholder analysis to derive more useful results and benefits for each stakeholder to be involved in sustainable management decision (Reed et al., 2009).

\subsection{Existing Management Practices and their Constraints}

The Sundarbans is managed through three wildlife sanctuaries. According to the definition of wildlife sanctuary, it means "an area closed to hunting, shooting or trapping of wild animals and declared as such under Article 23 by the Government as undisturbed breeding ground primarily for the protection of wildlife inclusive of all natural resources such as vegetation soil and water" (MOEF, 2005). Thus, the FD is managing its resources by addressing the need for wildlife conservation as early management emphasised revenue collection through resource extraction. In this connection, present management policy is directed to assure the sustainable harvesting of forest products and maintain this coastal zone in a way that meets the needs of the local human population. However, the Sundarbans is facing illegal felling by the timber merchants. This also happens due to high demands for fuel wood that is used for brick burning. Government controls wood pricing for fuel wood, bamboo poles, pulp and matchstick wood with other NWFPs including fisheries through allocating permits which are heavily underpriced. For example, in Khulna News Print mill, the royalty rate for Gewa is at US\$0.05 per cubic metre, as against its market price of about US\$10. Fuel wood royalties paid by industries to the government are only US\$0.63 per tonne, whereas the market price in Khulna is close to US\$50 per tonne (WB, 1991). Bamboo and pulpwood are also similarly under-priced. This policy encourages over harvesting.

The Sundarbans is very rich for its NWFPs which are under direct control of the FD. Shrimp is one of the most notable resources which is managed without any fishery management plan. Present shrimp farming in the Sundarbans is very unsustainable in terms of further breeding and growth and its conservation. The FD controls fishery resources through allocation of permits for fishing. At present the FD neither controls permit licenses to reduce overharvesting nor monitors fishing patterns to stop the catch of wild shrimp fry which is banned by regulations (Hoq, 2007).

Other than shrimp, the main NWFPs are Golpata, Hantal, Honey and Shell. Table 3 shows the declining trend of these NWFPs. In a survey, it was found that more than treble amount of permit fees are charged as bribes by the FD, police and dacoits for collecting NWFPs for which local people are the prime beneficiaries (Kabir and Hossain, 2008). Local people identified FD's malpractices and corruptions as the main reasons for the massive destruction and these have been on increase.

Bangladesh Forest Policy 1994 (GOB, 1994) clearly states in Para 1, “.....the Government shall work jointly with Non-Government Organisations and ensure people's participation". In Para 12 it further states, 
"Denuded an encroached Government forest lands will be identified and brought under afforestation program with people's participation on benefit sharing approach...”. In spite of clear policies for communityoriented management and their involvement under different projects since 1994, the FD did not involve them in planning and management of the Sundarbans. From the above analysis, it is also found that the FD introduced flawed PFM where participation was not ensured. This also shows the lack of FD's visionary outsights to realise it from overall perspectives.

\subsection{Choosing an Option: Community Based Forest Management (CBFM) for the Sundarbans}

The PFM programmes discussed above reveal that there is a significant change in livelihood and conservation due to community involvement. Sal forest experience proves PFM is useful to enhance interaction between livelihood of rural people and resource management (Safa, 2005). In neighbouring countries like India and Nepal, participatory forestry is implemented as a new paradigm for forest management. Specially, Nepal having failed to manage the forest through bureaucratic machinery recognised the only practical way of ensuring protection and sustainable supply of forest products by giving the responsibility for management to the villagers (Gautam et al., 2004). India also gained successes by introducing Joint Forest Management. The Sundarbans, being its multidimensional nature, is getting increased pressure from the local demand which needs to rearrange its prevailing management issues. Table 4 shows local people as the prime beneficiaries of the main resources other than wood products which are mainly targeted for the state-owned industries. However, under the control of FD, they have no role in contribution or participation in the conservation.

From Ministry of Environment and Forests, it is found that total number of beneficiaries from participatory forestry is 19,796 of whom BDTK. 255.16 (US\$1 = TK. 68) has been disbursed for 4944 hac of both wood and agricultural forest land covering along with the Strep Forest garden of 2,748 km (MOEF, 2009). This shows financial disbursement for recovering forest land outside the Sundarbans.

Table 3. Production trends of the main NWFPs of the Sundarbans

\begin{tabular}{|c|c|c|c|c|c|}
\hline Year & & $1990-91$ & $1989-90$ & $1986-87$ & 1980-81 \\
\hline \multirow[t]{4}{*}{ Golpata } & Production (in million $\mathrm{Kg}$ ) & 2.63 & 2.48 & 2.63 & 2.48 \\
\hline & Production (\% change) & +6.00 & 0.00 & +13.00 & - \\
\hline & Revenue (in million US\$) & 0.15 & 0.17 & 0.10 & 0.05 \\
\hline & Revenue (\% change) & +13.00 & +67.00 & 0.00 & - \\
\hline \multirow[t]{4}{*}{ Hantal } & Production (in tonnes) & 6.70 & 7.20 & 6.10 & 6.20 \\
\hline & Production ( $\%$ change $)$ & -6.00 & -13.00 & +12.00 & - \\
\hline & Revenue (in thousand US\$) & 8.37 & 8.48 & 4.26 & 0.617 \\
\hline & Revenue (\% change) & -1.00 & +57.00 & +19.00 & - \\
\hline \multirow[t]{4}{*}{ Honey } & Production (in tonnes) & 211.00 & 147.00 & 229.00 & 311.00 \\
\hline & Revenue (in thousand US\$) & 13.40 & 15.50 & 4.60 & 3.01 \\
\hline & Beeswax (in tonnes) & 53.00 & 37.00 & 58.00 & 75.00 \\
\hline & Beeswax revenue (in thousand US\$) & 5.28 & 4.90 & 2.30 & 1.50 \\
\hline \multirow[t]{2}{*}{ Fish } & Production (in tonnes) & 4.80 & 5.10 & 6.80 & - \\
\hline & Revenue (in million US\$) & 0.35 & 0.29 & 0.17 & 0.026 \\
\hline \multirow[t]{2}{*}{ Shell } & Production (tonnes) & 2.40 & 2.90 & 3.20 & - \\
\hline & Revenue (in million US\$) & 1.64 & 1.64 & 1.10 & - \\
\hline
\end{tabular}

Source: Adapted from Roy (2009a)

Table 4. Wood and NWFPs distribution

\begin{tabular}{llll}
\hline Species/others & Method & Agency & Prime beneficiary \\
\hline Wood products & Government distribution policies & FD & Industry \\
Golpatta & Government policies & FD & Local people \\
Hantal & Government policies & FD & Local people \\
Fish, Prawn \& Shells & Government policies & FD & Local people \\
Hogla & -- & -- & Local people \\
Tourism & Government policies & FD \& BPC & Government and local people \\
Miscellaneous & -- & FD & Local people \\
\hline
\end{tabular}

Source: Roy (2009a) 
Table 5. Policy directions and international obligations for CBFM for conservation

\begin{tabular}{|c|c|c|c|}
\hline $\begin{array}{l}\text { Policy objectives for the } \\
\text { Sundarbans (GOB, 1994) }\end{array}$ & $\begin{array}{l}\text { National and international } \\
\text { obligations }\end{array}$ & International endorsements & $\begin{array}{l}\text { Potential benefits of CFM in } \\
\text { the Sundarbans }\end{array}$ \\
\hline $\begin{array}{l}\text { Manage to meet the present } \\
\text { and future basic needs of } \\
\text { the people }\end{array}$ & $\begin{array}{l}\text { Emphasis of afforestation } \\
\text { to ensure supply. }\end{array}$ & Sustainability & $\begin{array}{l}\text { Use of marginal and khas } \\
\text { land. Encourage social } \\
\text { forestry. }\end{array}$ \\
\hline \multirow{4}{*}{$\begin{array}{l}\text { Creation of employment } \\
\text { and forest-based economy } \\
\text { Involvement of local people }\end{array}$} & Poverty alleviation & $\begin{array}{l}\text { Achieve MDGs (NSAPR, } \\
\text { 2008) }\end{array}$ & $\begin{array}{l}\text { Improvement of the economic } \\
\text { status of local poor community. }\end{array}$ \\
\hline & Collaborative management & $\begin{array}{l}\text { Ensure partnership } \\
\text { (UN, 1992) }\end{array}$ & $\begin{array}{l}\text { Increased customary right, power } \\
\text { in decision-making and } \\
\text { development of ownership. } \\
\text { Reduced illegal felling and } \\
\text { hunting cap over extracting }\end{array}$ \\
\hline & Commitment & Accountability (UN, 2000) & $\begin{array}{l}\text { Accountable and transparent } \\
\text { management enhance credibility. }\end{array}$ \\
\hline & Stop dacoity and harassment & $\begin{array}{l}\text { Equality and basic rights } \\
\text { (UN, 2000) }\end{array}$ & $\begin{array}{l}\text { Equal sharing of the benefits } \\
\text { without discrimination. }\end{array}$ \\
\hline \multirow[t]{4}{*}{$\begin{array}{l}\text { Contribution to GDP and } \\
\text { conservation of nature }\end{array}$} & $\begin{array}{l}\text { Pro-poor economic growth } \\
\text { by increasing present GDP } \\
\text { contribution from } 3 \% \text {. }\end{array}$ & $\begin{array}{l}\text { Remove unequal distribution } \\
\text { of resources (APR, 2008) }\end{array}$ & $\begin{array}{l}\text { Trained people with customary } \\
\text { knowledge for better } \\
\text { understanding and } \\
\text { responsibilities. Development of } \\
\text { sharing attitude. }\end{array}$ \\
\hline & $\begin{array}{l}\text { Conversation of biodiversity } \\
\text { and resources with ecological, } \\
\text { economic and social } \\
\text { considerations. }\end{array}$ & $\begin{array}{l}\text { Bangladesh signed } \\
\text { Convention on Biological } \\
\text { Diversity held at Rio De } \\
\text { Janeiro for Environmental } \\
\text { and economic sustainability } \\
\text { (UN, 1992) }\end{array}$ & $\begin{array}{l}\text { Preserve resources and species } \\
\text { with the endangered ones. }\end{array}$ \\
\hline & $\begin{array}{l}\text { Preservation of the Wold } \\
\text { Heritage }\end{array}$ & $\begin{array}{l}\text { Declaration } \\
\text { of the Sundarbans as World } \\
\text { Heritage Site }\end{array}$ & $\begin{array}{l}\text { Eco-tourism other than } \\
\text { resources brings inflow of } \\
\text { revenue. }\end{array}$ \\
\hline & $\begin{array}{l}\text { Change top-down policy } \\
\text { and involvement of all } \\
\text { stakeholders }\end{array}$ & $\begin{array}{l}\text { Capacity development } \\
\text { (APR, 2008) }\end{array}$ & $\begin{array}{l}\text { Benefit-sharing and equal } \\
\text { distribution to all including the } \\
\text { poorest. }\end{array}$ \\
\hline
\end{tabular}

Fishing is banned in the sanctuaries which are $23 \%$ of the total areas of the Sundarbans. Rest of the area is open for fishing except the small lakes where fishing is prohibited on every alternative year. This openness encourages commercial shrimp farming with an increased interest of local elites to treat this aquaculture as Blue Revolution, akin to agricultural Green Revolution of mid-sixties. Several studies reveal that large-scale commercial shrimp aquaculture is least desirable in terms of degradation and comparative evaluation of policy scenarios from ecological and social perspectives (Knowler et al., 2009).

In consideration of the present trend of resource extraction, CBFM may be considered as the alternative strategies to reduce degradation by allowing community in management with defined property rights and decision-making power. Otherwise, due to a lack of ownership and alternative sources of income, poaching, illegal felling, over and unauthorised harvesting will cause continuous degradation of this forest. CBFM is also supported by the policy directives and endorsed in various government and international obligations. This is narrated in Table 5.

\section{CONCLUSION}

Bangladesh has made the target to achieve eight Millennium Development Goals (MDGs) of which number seven is to 'ensure environmental sustainability' although the Sundarbans remains vulnerable to over harvesting and degradation. State monopoly with the sole power for forest bureaucracy and top down approaches for the management of this mangrove forest need to be critically evaluated as they have progressively become ineffective to stop depletion; rather, it is on rampant. Forest management strategies including the role of FD also need to be redefined to meet the needs of local communities. To reduce degradation and to promote its sustainable management, government may initiate innovative opportunities by decentralising administrative authority and responsibility to local organisations controlled by local communities with the establishment and strengthening local institutions to ensure their participation. 
The policy dimension is always in the process of becoming with the combination of economic and social structure which essentially needs necessary dynamic adjustments for achieving sustainability. Thus, participatory management may be the most appropriate alternative for sustainable management of the Sundarbans.

\section{REFERENCES}

APR, 2008. Support to monitoring PRS and MDGs in Bangladesh. Planning Commission.

Gautam, A.P., G.P. Shivakoti and E.L. Webb, 2004. A review of forest policies, institutions and changes in the resource condition in Nepal. Int. Forestry Rev., 6: 136-148. DOI: 10.1505/ifor.6.2.136.38397

GOB, 1994. Bangladesh forest policy 1994.

Hakim, S.S., 2007. Ecotourism and the Sundarbans: Alternative Policies for Development. 1st Edn., University Grants Commission of Bangladesh, Dhaka, ISBN-10: 9848090355, pp: 101.

Hoq, M.E., 2007. An analysis of fisheries exploitation and management practices in Sundarbans mangrove ecosystem, Bangladesh. Ocean Coastal Manage., 50: 411-427. DOI: 10.1016/j.ocecoaman.2006.11.001

Islam, S.S., H.C. Sim, S. Appanah and N. Hooda, 2005. Poverty alleviation and forest conservation in Bangladesh: Role of research. Proceedings of the workshop on forests for poverty reduction: Changing role for Research, Development and Training Institutions, Jun. 17-18, Dehradun (India), pp: 193-201.

Kabir, D.M.H. and J. Hossain, 2008. Resuscitating the Sundarbans: Customary Use of Biodiversity and Traditional Cultural Practices in Bangladesh. 1st Edn., Unnayan Onneshan--The Innovators, Dhaka, pp: 98.

Khan, M.H., G.M. Sarwar and J. Islam, 2008. Climate change and strategic adaptation provisions for coastal Bangladesh: National seminar on Mangrove for Sustainable Livelihood and Adaptation to Climate Change.

Knowler, D., N. Philcox, S. Nathan, W. Delamare and W. Haider et al., 2009. Assessing prospects for shrimp culture in the Indian Sundarbans: A combined simulation modelling and choice experiment approach. Marine Policy, 33: 613-623. DOI: 10.1016/j.marpol.2008.12.009

Misra, D. and S. Kant, 2005. Economic efficiency and shadow prices of social and biological outputs of village-level organizations of joint forest management in Gujarat, India. J. Forest Econ., 11: 141-160. DOI: 10.1016/j.jfe.2005.07.002

MOEF, 2005. Forestry sector project-area covered and beneficiaries.

MOEF, 2009. Mangrove forests.
Muhammed, N., M. Koike, F. Haque and M.D. Miah, 2008. Quantitative assessment of people-oriented forestry in Bangladesh: A case study in the Tangail forest division. J. Environ. Manage., 88: 83-92. PMID: 17379393

Muhammed, N., M. Koike, M. Sajjaduzzaman and K. Sophanarith, 2005. Reckoning social forestry in Bangladesh: Policy and plan versus implementation. Forestry, 78: 373-383. DOI:10.1093/forestry/cpi045

NSAPR, 2008. National strategy for accelerated poverty reduction-II

Reed, M.S., A. Graves, N. Dandy, H. Posthumus and K. Hubacek et al., 2009. Who's in and why? A typology of stakeholder analysis methods for natural resource management. J. Environ. Manage., 90: 1933-1949. PMID: 19231064

Roy, A.K.D., 2009a. Wetland Management and Valuation: The Sundarbans Perspective for Participatory Forestry. 1st Edn., Academic Press and Publishers Library, Dhaka, ISBN-10: 9840802496 , pp: 96.

Roy, A.K.D., K. Alam, J. Gow, 2012. A review of the role of property rights and forest policies in the management of the sundarbans mangrove forest in Bangladesh. Forest Policy Econ., 15: 46-53. DOI: 10.1016/j.forpol.2011.08.009

Roy, P., 2009b. Forest-hostile projects deforesting Madhupur. Donors favour plantation of foreign species; locals keep trust in natural forest. The Daily Star.

Safa, M.S., 2005. Poverty-environment interaction through participatory forest management in Bangladesh: An evidence of poverty reduction.

Safa, M.S., M.R. Siddiqui, A. Asanoy and A. Abdu, 2004. Financial Viability of small farm forestry based on no-cost sharing arrangement in Sal (Shorea robusta) forest of Bangladesh. Proceedings of Human Dimensions of Family, Farm and Community Forestry International Symposium, Mar. 29-Apr. 1, Washington State University, Pullman.

Stone, K., M. Bhat, R. Bhatta and A. Mathews, 2008. Factors influencing community participation in mangroves restoration: A contingent valuation analysis. Ocean Coastal Manage., 51: 476-484. DOI: 10.1016/j.ocecoaman.2008.02.001

Tamang, K.M., 1994. Integrated Resource Development of the Sundarbans Reserved Forest Bangladesh. 1st Edn., Food and Agriculture Organization of the United Nations, Khulna, pp: 120.

Tewari, D.D., 2006. The effectiveness of state forest development corporations in India: An institutional analysis. Forest Policy Econ., 8: 279-300. DOI: 10.1016/j.forpol.2004.09.002

UN, 1992. United Nations Conference on Environment and Development. United Nations,

UN, 2000. United Nations Millennium declaration and millennium development goals.

WB, 1991. Bangladesh Environment Strategy Review. 1st Edn., World Bank, Washington DC, pp: 73. 